MARY PARR and E. J. HUMESTON, JR.

\title{
Library School Placement
}

Good placement programs in library schools begin when applications are received for admission. All data collected at that time, together with a graduate's academic record while in library school, the faculty's evaluation of him, and reports of jobs held while in library school, are part of a good placement dossier. In a successful program great attention must also be given not only to recommending current graduates but in motivating older alumni as well. The maintenance of comprehensive, easily-tapped records is essential, and hospitality must be accorded recruiters.

I

MIBRARY SCHOOLS are often queried about their placement programs. Both librarians and the laity inquire of the library educator, "What about your placement program?” This question sometimes seems to be half inquiry and half accusation.

Probably no one connected with library schools or library education knows of a single placement program in existence with which he is completely pleased, however a number of library schools appear to do quite a good placement job despite the fact that the concept of a placement program in today's library school is far broader than locating positions for this year's graduates.

What makes a "good" placement program in a library school? Let us begin at the beginning. In truth, the placement program should begin the day the application for library school is received by school officials. This application, together with subsequent steps for enrollment, should determine as nearly as possible the applicant's placement potential. No administrator who has interest in either the profession as a whole or "his" library school as part can con-

Miss Parr is Assistant Professor of $\mathrm{Li}$ brary Science at Pratt Institute, and $\mathrm{Mr}$. Humeston is Dean of the Graduate Library School at the University of Rhode Island. scientiously consider for enrollment the individual for whom he cannot conceive a niche at the termination of his library school education and for the duration of his professional career.

Those library schools which see placement in these terms develop a pattern to insure themselves, in so far as possible, against future placement problems. At Drexel, for example, a carefully examined program is executed, step by step. By viewing each applicant as a long-term successful librarian, Drexel has endeavored to decide what the ascertainable characteristics are that determine success and how it should collect this information.

\section{Data Gathering}

Assuming that the individual's academic record is important, transcripts of all of his endeavors in higher education are requested. In addition, the library school requires three letters of recommendation, preferably from those who have known the applicant in the capacity of student or employee. Combining these letters with transcripts and the completed, well-drafted application is the beginning of a judgment.

With these data assembled only a paper picture of the potential librarian emerges-usually accurate, sometimes not. Many of the Drexel applicants will 
have had an interview prior to their formal application with the library career consultant who is part of the Drexel faculty. The report of his interview can be of major significance. If there is doubt about the desirability of a given applicant, it is always possible that he be interviewed by the dean or other faculty members. Certainly no individual is admitted about whom the school has serious doubts in the matter of job placement.

Drexel, as any other library school, will admit that transcripts, three letters of recommendation, and an interview collectively will not reveal the many sides of any given individual. Chances are small that anyone will soon devise a method which will. It is simple enough to eliminate the scholastically weak by requiring a $B$ average for admission, but what about those otherwise acceptable students, even though they be a small minority, who subsequently exhibit serious emotional immaturity, lack of integrity, or slovenly habits?

\section{Faculty Evaluations}

Once the individual has been admitted as a student those most apt to discover the qualities which will make this person a placement problem are the faculty. For this reason faculty evaluations are continuously carried on. These evaluations are brought to the attention of the faculty group at its meetings. Whenever it believes such action justified and essential for the protection of the school and the profession, the faculty votes to dismiss students for whom it has serious fears, on the grounds that they have shown themselves unfit or exceedingly poor risks for librarianship. The faculty does this type of "weeding" the moment it seems necessary, knowing well the cost in money, time, and effort to the individual.

There will always be those students about whom there are doubts not quite serious enough for dismissal. What about them? The tendency is to give the dubi- ous the benefit of the doubt remembering that the needs are great and that some people change. This, however, does mean that Drexel makes certain it knows precisely what its reservations are about such graduates and that in a final analysis it can be said that the individual's chances for success outweigh his chances of failure.

\section{ReCOMMEND OR LIST}

One of the continuing controversial questions relating to placement is whether schools should recommend graduates for specific positions or simply list them as having had the courses and experience required for a specific job. Actually, Drexel does both. If a number of individuals have the necessary qualifications for a particular position, it sends credentials on all of them, sometimes suggesting that Applicant A's personality may fit him better for the position than Applicant B's. If it has no one in its files who meets the requirements, the school may suggest the names of others who almost meet them or might meet them with inservice training or independent study on the job. All this represents a more liberal policy than was previously employed. The placement office is entirely content to see graduates interested in and succeed in crossing into aspects of library work in which they have not majored. Taking into account the shortage of librarians and the desire of some to explore new avenues, there will doubtless continue to be an appreciable amount of such shifting of fields. Despite the fact that they are often well qualified for other positions, however, the school must sometimes discourage those few individuals who seek positions for which they are not at all qualified.

\section{A Continuing, Cooperative Thing}

One of the accusations often made against placement programs is that not only do they fail to make the best use 
of available manpower but they also fail to offer the graduate any assurance that he will be helped to attain his potential. Certainly this accusation is not without basis, but of greater importance is the reason that this is true. Many library schools make a continuing effort to keep in touch with their graduates and to advise them of positions which will help them improve themselves.

Drexel has discovered in many instances that the fault lies with the graduate rather than the school. Many continually fail to respond to questionnaires as to their whereabouts and their job preferences. However, Simpson ${ }^{1}$ reports the findings of a study which indicates that "All schools attempt to place the graduate throughout his career and 52 per cent of the schools recommend any qualified graduate for a position regardless of whether the graduate has indicated an interest in a change of position."

\section{Pre-professional Placement}

Internships and full and part-time preprofessional positions are an important part of the work of the placement officer. Many Drexel students consult the placement office hoping to find workstudy positions which will help them finance their studies. Positions secured in this way and subsequent evaluations by the employers of the students in such positions contribute to the files on the students' capabilities and effectiveness on the job. Often these evaluations have great bearing on future professional placement. Pre-professional placement within a library system sometimes becomes professional placement upon graduation. Pre-graduate experience has also been a consideration when determining salaries for new graduates. In these ways this type of placement becomes an important part of the over-all placement program.

\footnotetext{
${ }^{1}$ Martha Simpson, "Placement Systems in Library Schools," Journal of Education for Librarianship, I (Spring 1961), 219.
}

\section{ReCRUITERS WeLCOME}

Recruiters from large and small libraries are welcomed and scheduled for interviews with interested students and whenever possible for talks before groups of students prior to such interviews. Printed materials describing any given library system which are sent to the Drexel placement office are made available to all graduates. This type of information is helpful to both the office and the individual in making a knowledgeable decision.

\section{Mechanics}

The mechanical aspects of placement operations probably differ little from school to school. Most maintain the following types of student information:

1. Card files of all graduates, each tabbed for varying qualifications, for different types of work, for interest in geographical location and salary range;

2. Faculty evaluations of each student;

3. Letters of reference written at time of admission;

4. Employer evaluations of both preprofessional and professional employment;

5. Photographs of all current and most recent graduates.

The companion piece to the student files at Drexel is the ever-bulging one that supplies current information about the twenty-six hundred vacancies it has been requested to fill in the past year. This file includes information indicating:

1. Position vacant

2. Job description

3. Qualifications

4. Salary ranges

5. General information about specific system

6. To whom to apply

In addition to these files a good placement program makes provision for (1) maintaining statistics on placement ac- 
tivities, (2) scheduling recruiters, (3) dealing with problems of foreign students, (4) keeping alumni records up to date by sending questionnaires to both graduates and employers, (5) knowing of available financial aid (other than part or full-time employment), (6) sending confidential data upon request, (7) listing part and full-time job opportunities, (8) recording names of current students seeking pre-professional employment, (9) maintaining relations with the Alumni Association officers and the alumni secretary concerning honors, fund-raising, and social affairs, and (10) maintaining a bulletin board display of recent vacancy lists. All of these tasks are part of the expanded version of library school placement, together with varied unique problems which present themselves frequently.

It should also be noted that a good placement program has as its officer one who makes an honest effort to know library systems and individuals in these systems as well as knowing personally as many as possible of the school's current students and former graduates.

\section{Degrees of Success}

The degree of success attained by any given library school's placement program is almost impossible to measure. Initially it is difficult to find the yardstick. If a given school has no graduates desirous of employment whom it cannot place is then its program a success? Or does this simply indicate that shortages are great and that individuals often secure positions for themselves? If alumni are questioned about their satisfaction with their institution's placement program and reply with little or no negative comment, has the placement office succeeded? Or does this indicate that they do not respond to questionnaires in general? Is it perhaps as important if a system representative comes to a library school again saying that he would like to employ another of your gradu- ates? Or is the school geographically their "best bet"?

From the point of view of a library school placement program, it seems evident that success is at least a two-way street. For the program to measure up, both individual and system must find some degree of satisfaction. In any effort to measure the effective use of manpower, the absolutes are very difficult to discern, largely because there is no real basis for judgment and often because the systems are at fault for not utilizing individual abilities. To try to measure the degree of success of its present placement program Drexel has solicited reactions from graduates and employers. Those reactions to date seem highly favorable, implying ample satisfaction. Current students are placed with great frequency well ahead of the completion of their studies. From a quantitative standpoint the number of changes on the part of former graduates seeking better positions has increased more than 100 per cent in the last six years. All this would seem to indicate a placement program that is enjoying at least a reasonable degree of success.

\section{Forecast}

As the profession matures it seems reasonable to assume that all library schools will concern themselves with selecting from their applicants by a series of devices, those individuals for whom they cannot foresee a continuing successful career in librarianship. Those individuals who measure up initially will be constantly evaluated, and whenever serious problems manifest themselves, academic or nonacademic, the student will be dismissed. In those instances where mistakes have been made and an individual has graduated and cannot be placed after several efforts, the placement offices will discontinue efforts on that individual's behalf. Placement programs will make every effort to put the best person in the best situa- 
tion as most of them try to do now. Once persons are placed the library schools will continue to follow their graduates' progress closely and help them whenever possible to attain their professional potential. Placement officers will help place graduates of other library schools as well as their own whenever possible. The library schools' placement programs must make every effort to upgrade and refine but with the help of the library world in which they live.

\section{REFERENCE LIBRARIAN}

(Continued from page 310 )

service has become scattered and diluted.

Some divisions have been staffed with only one professional librarian, and as most academic libraries are open more than ninety hours a week, the specialist is available for less than half of the open hours. One might also ask, in what Mecca is there to be found a subject librarian who does not have also to be involved in administrative responsibility and in supervising such tasks as scheduling, amassing statistics, housekeeping of the area, filing reports, and so forth, and is only interrupted from his bibliographic pursuits by a faculty member or $\mathrm{PhD}$ candidate. The librarian cannot hope to spend the full forty hours he is at work rendering subject reference service. If one is fortunate to have welltrained career nonprofessionals available, they can substitute in his absence. Often student pages are filling in the gap.

The philosophies of library administration and organization that form the pattern of public services depend on too many local factors to allow analysis in detail. In general terms, the current divisional structure, if carried to extremes, risks completely supressing bread-andbutter service along with the general reference librarian. This important aspect of library service would be relegated to an information clerk sitting in splendid isolation by the umbrella stand giving traffic directions. Or it would fall by default to the clerks checking brief cases at the entrance or handling circulation work in the lobby. As Everett Moore has observed, the lack of a central reference service near the main card catalog leaves the patron in a state of confusion with nowhere to turn for assistance. Some libraries have established a token information center when the division plan of service removed the main reference desk and the situation became less than tolerable. Unfortunately, it is often impossible to reestablish a main reference desk when a building has been planned for divisionalized service. ${ }^{6}$

If the undergraduates are to receive good service and if bread-and-butter service is to survive, the general reference desk must be retained even in a divisional-oriented library. If possible, the desk should be in the proximity of the main card catalog, the first port of call, near the main entrance to the building. It should be more than an information and directional desk; it should have access to a general reference collection. In a completely divisionalized organization, the separate divisions often take on the aspects of separate libraries. Some college and university libraries are to all intent and purpose, four or five individual libraries in one building. There is need for one main desk which will not only handle informational and instructional problems, but which can deal as well with the reference needs of patrons who do not need the "in depth" help of the subject specialist; can refer the patron to the proper divisional desk; and can handle reference situations when the divisional desks are not manned. This main reference desk should be staffed at all times by professional librarians who are knowledgeable in all aspects of the profession and in the operations of their library, and they should be sympathetic toward bread-and-butter service.

- Moore, op. cit., p. 365 . 